\title{
ISSUANCE OF SECURITIES BY PUBLIC SERVICE CORPORATIONS*
}

\author{
, IRWIN S. RosenbaUm aNd David E. LILIENTHaL
}

Security issues by public service corporations now exceed in volume and importance the securities of all other corporations. ${ }^{1}$ The processes of commission regulation of these issues becomes therefore increasingly vital and an examination of commission regulation in this field needs no further justification. New York has been the pioneer in effective security regulation. Its commission deals with large scale operations and has had before it an innumerable variety of problems; its state statutes and commission's practices have been followed in most other states. ${ }^{\text {in }}$ Accordingly, a study of this commission in action tells the story of security regulation not only in New York but throughout the country.

\section{LEGISLATIVE HISTORY OF REGULATION}

The earliest permanent commission created in New York for the regulation of public utilities, other than merely to report information, was the State Board of Railroad Commissioners. This body was created in $1855 .^{2}$ On it were conferred duties and powers somewhat extensive for that early date, such as the issuance of certificates prior to operation, power to inspect bools, the reporting of accidents, enforcement of the laws pertaining

\footnotetext{
*The material contained in this article has been collected for use in a service dealing with the legislation and decisions of various states concerning Public Utilities Regulations. The Service is to be published in the near future by the Commerce Clearing House and Corporation Trust Company.

I "Since 1921 the financing of steam railways and other public utilities in each year constituted over one-half of the par value of all corporate issues. In 1924, for instance, 65 per cent of new corporate security issues were by railway and public utility corporations." Dorau, Public Utility Financing (1919-1925) 1 Jour. LaNd \& PUB. UTIL. Ec. 306, reprinted in LAGerquist, PUblic Utility FinaNCe (1927) 253.

1a For a detailed analysis of the various state laws dealing with issuance of securities of public service companies see Waltersdorf, State Controt of Utility Capitalization (1928) 37 YALE LAw Journal 337.

A bibliography for material dealing with the regulation of security issues of railroads and other utilities may be found in BONBRIGHT, RAILROAD Capitalization (1920) App. D (Studies in Histories, Economics and Public Law of Columbia University, Vol. XCV, No. 1).

$2 \mathrm{~N}$. Y. Laws 1855 , c. 526 . For a brief history of state regulation in Now York, see 1 N. Y. Pub. Ser. Comm., 1ST Dist., ANṆUAL REP. For 1907, 451 et seq.
} 
to railroads and the like. But the Board had a short life, and after two stormy years it finally succumbed to the onslaugh ${ }^{+}$ of adverse railroad interests. ${ }^{3}$

After long years of agitation and some half dozen years of legislative manipulation, the Legislature finally revived the Commission in 1882.4 The new Board of Railroad Commissioners thus created was similar in nature to the old Board. But it was decidedly "weak" in the powers delegated it, and in authority to enforce its orders.

In no respect, perhaps, did its powers prove less efrective than in that of supervision over security issues. The Board was dominated by railroad interests, and its power's were so limited as to render effective regulation very difficult indeed. Its approval of increases of capital stock and the issuance of mortgages and mortgage bonds were mere perfunctory proceedings, evidently granted largely as a matter of course and placing no real restraint on unfortunate and improper financing only too often resorted to by railroad companies during that period."

3 The Act of 1855 was repealed by N. Y. Laws 1857, c. 633.

$+N$. Y. Laws 1882 , c. 353 .

5 The membership of the old Board consisted of the State Engineer and Surveyor, one person appointed by the Governor with the consent of the Senate, and one elected by the board of directors of the railroads. The new Board was at first appointed by the Governor with the conscnt of the Senate, one member each on the recommendation of the Chamber of Commerce of the State of New York, the New York Board of Trade and Transportation, and the National Anti-Monopoly League of New York. The other two members were elected to represent the Republican and Democratic parties. In 1890 these limitations on the appointive power of the Governor were removed. N. Y. Laws 1890 , c. 565, $\$ 150$.

"The powers of the Commission were quite limited. No effective method was provided for the enforcement of its orders and recommendations. At the time of the creation of the New York Commission in 1882 there were in the various states numerous railroad commissions, and these have been classified as 'strong' or 'weak' commissions, according as their function was that of control, extending to the making of rates, or merely that of supervision and recommendation. The New York Commission was in this sense distinctly a 'weak' commission. Its reports to the Legislature contain frequent reference to the disregard on the part of the companies of its orders and recommendations and to its inability to enforce the same." 1 N. Y. Pub. Ser Comm., 1St Dist., Annual Rep. For 1907, 454.

6 The tendency of the Board of Railroad Commissioners to approve practically every application for increase of capital stock or issuance of securities may be gathered from the summary of its approvals during the typical years 1903 and 1906 . In the first of these years, out of thirteen applications for increase of capital stock, it approved all but two applications and one of these it disapproved because it was not made in proper form. The total increase approved was $\$ 33,905,000$. I N. Y. Bonno of R. R. CoMm'rs, ANNUAL ReP. FOR 1903, 248, 256. Out of nineteen applications for the issuance of mortgages and bonds, it disapproved only two and one of these was based upon the fact that it had no juriediction to 
Professor Ripley has pointed out the weakness of the Board of Railroad Commissioners and its inability to cope with the situation. He said:

"For many years the old railroad commission had been an utter nonentity, abjectly subservient to the powerful railroad and trolley companies. In 1893, just before the formation of The Metropolitan Street Railway, when, for some reason, the Commission refused its approval of a $\$ 6,000,000$ stock increase of the Pavonia Ferry Road, Thomas Ryan and his friends had the securities printed just the same and then exchanged them for a like amount of Metropolitan Street Railway stock. To this high-handed proceeding the railroad commission interposed no objection." 7

The act creating the Public Service Commission abolished the Board in 1907, and placed in its stead a commission equipped and empowered to handle the difficult problems of financial regulation. ${ }^{8}$

During these early years, public service corporations other than railroads were practically unrestricted as to the character and amount of their security issues. In the organization of such

make a nune pro tunc order. In two other of these applications, it granted approval on the condition that outstanding securities be retired by part of the proceeds. Ibid. 257, 270.

In 1906 the Board approved fifteen applications for increase of capital stock and denied none. One approval was made on condition that an equal amount of other securities be retired. Out of twenty-two applications for the issuance of mortgages and bonds, it denied only one. $1 \mathrm{~N}$. Y. BOARD of R. R. Conm'rs, ANNUAL Rep. For 1906, 247 et seq.

In contrast to this general policy of approval of practically all applications, we have the record of the Public Service Commission of the First District, which from July 1, 1907, to December 31, 1912, had presented to it forty-five applications for issuance of securities by transportation companies, of which number seven were pending at the time and eight had been withdrawn. The total amount applied for was $\$ 318,176,284$; amount allowed $\$ 207,536,819$; amount not allowed $\$ 97,577,311$; applications withdrawn $\$ 3,240,000$; and amount pending $\$ 9,822,154$.

During this time, thirteen applications were made by lighting companies, of which three were withdrawn. The amount applied for was $\$ 80,107,400$; the amount allowed $\$ 22,656,400$; amount not allowed $\$ 54,201,000$ (of this amount a single denial of $\$ 46,000,000$ was material) ; and applications withdrawn $\$ 3,250,000$. 1 N. Y. Pub. Ser. Comm., 1St Dist., ANNunt, Rep. For 1912, 252-253. These figures show a relatively high mortality in issues passed on by the Commission.

7 Ripley, Railroads, Finance and Organization (1915) 286, 287.

${ }^{8}$ N. Y. Laws 1907 , c. 429 . "That the Public Service Commissions Law has been effective in checking the indiscriminate flotation of stocks and bonds without adequate or proper security is shown by the fact that out of 199 millions of dollars, of purposes to which the proceeds of securities authorized to be issued in the current year were devoted, but $\$ 526,000$ has been required to be certified as being chargeable to operating expenses or to income for costs of replacements or other losses." N. Y. PUB. SER. ComM., 2D Dist., ANNual Rep. For 1917, xxii. 
new corporations, the directors were arbiters of the value of the property turned in, except in case of fraud, and the corporation was subject to no supervision to determine if its subsequent issues were for statutory purposes. The inevitable result followed. Watered stock and fictitious securities were placed on the market, and led, or were thought to lead, to loss to investors and increased rates to consumers. ${ }^{3}$

Accordingly, the Gas Commission Law, passed in 1905, contained a provision giving the Gas Commission regulatory jurisdiction over the issuance of securities by gas and electric companies. ${ }^{10}$ The provision was more general in its terms than the present act. It did not state definitely the purposes for which securities might be issued, but merely prohibited the issuance of securities or increase of capitalization until the Commission should "certify, in writing as to the amount of stocks or bonds reasonably required for the purposes of the corporation." It further provided for a hearing before the Commission and an investigation by it of "the value of the property and franchises owned and operated by such corporation."

Two years later the Public Service Commission Law was enacted.11 Its provisions superseded and extended commission control over security issues. Sections 55 and 69 of that act provided for general commission regulation of securities issued by common carriers, railroads and gas and electric companies, among others. The provisions stand now in substantially the same form as they were passed. The only important changes are that to section 55, in 1910, whereby the provision allowing reimbursements of the treasury was added, ${ }^{12}$ and that adding sec-

9 "Prior to the Gas Commission Law the corporation itself was practically the judge of what bonds and stock were required for the purposes of the company. Section 42 of the Stock Corporation Law, which permitted the issue of stock for property and labor, provided that the stock should be considered fully paid up and in the absence of fraud in the transaction the judgment of the directors as to the value of the property purchased was conclusive. The fact that the directors of the company might fix the value upon the property turned into the company and paid for by stock was a prolific source of stock watering and of fictitious securities issued by corporations. Section 12 of the Gas Commission Law was intended to malie the consent of the Commission to the issue of new stock and bonds a certain check upon the directors and stockholders of such companies." In re Watertown Gas Light Co., 127 App. Div. 462, 464, 111 N. Y. Supp. 486, 489 (3d Dept. 1908).

${ }^{10} \mathrm{~N}$. Y. Laws 1905 , c. $737, \S 12$ This act was paszed after twenty years of agitation. See 1 N. Y. PUB. Ser. Comar., IST Dist., ANNull Rep. for $1907,451$.

11 N. Y. Laws 1907 , c. 429 , $\S \S 55,69$.

12 N. Y. Ann. Cons. Laws (2d ed. 1917) c. 48, §55; see N. Y. Laws 1910, c. 480 . This change did not appear in N. Y. Cons. Laws (1910) as the Public Service Law was not signed by the governor until the year following. 
tions $55 \mathrm{a}$ and $69 \mathrm{a}$ in 1912 , whereby the Commission was given extended jurisdiction over reorganizations and security issues in connection therewith. ${ }^{13}$ Some minor changes were made in these provisions in 1921.14 In the year 1910, also, the jurisdiction of the commissions were extended to include telegraph and telephone companies and their capitalization; in 1913, it was applied to steam corporations. ${ }^{15}$

The commissions soon found that their duties in respect to the issuance of securities consumed a substantial part of their time and involved some of the most important problems before them. ${ }^{16}$ For example, in the year 1908, out of twenty-five applications made to the Public Service Commission of the First District for certificates of various sorts, eight were for the approval of security issues. ${ }^{17}$ The Public Service Commission of the Second District at the very start adopted the policy of having its representatives check over the books of companies under its jurisdiction and of comparing the data thus obtained with the evidence presented before it ex parte on application for authority to issue securities. In 1909, it instituted an ambitions program of examining books and accounts of all companies under its jurisdiction, and accordingly found it necessary to or-

${ }^{13}$ N. Y. Laws 1912 , c. 289 . The present discussion docs not take up the problems involved in the issuance of securities in, and the methods of effecting, a reorganization or consolidation. That subject warrants a detailed and separate analysis.

14 Sections 55a, 69a and 101a were amended by N. Y. Laws 1921, c. 134. Sections 55 and 69 were amended by the same law, as indicated above. Section 101 remained unchanged.

${ }_{15} \mathrm{~N}$. Y. Laws 1910 , c. 673 , effective June 25,1910 ; N. Y. Laws 1913 , c. 505, effective May 14, 1913.

16 "These provisions of the section under consideration, viz.: that in overy order authorizing the issue of stocks, bonds, notes or other evidence of indebtedness there shall be a statement that in the opinion of the Commission the use of the capital to be secured by the issue of such stock, bonds, notes or other evidence of indebtedness is reasonably required for the said purposes of the corporation, the Commission deems to be wiso and practically indispensable to the proper working of the law, but it is obvious that it imposes extremely great labors upon the members of the Commission. It practically requires every member of the Commission, or at least a majority of the same, to examine with care every application of this character.

"The Commission, in disposing of these cases, practically sits as a court, and decides upon evidence presented to it questions of fact. These questions of fact, while sometimes simple and easily disposed of, are in many cases exceedingly complex and require minute and laborious investigation." N. Y. Pub. Ser. Comm., 2d Dist., ANnual Rep. FOR 1907, 21.

${ }_{17}$ See 1 N. Y. PUB. Ser. Comm., 1ST Dist., ANnual Rep. for 1908, 113114. For the scope of work of the Commission of the Second District, see N. Y. PUB. Ser. Comm., 2D Dist., ANNUAL ReP. FOR 1915, xliv et seq. 
ganize a Division of Capitalization to conduct these accounting examinations. ${ }^{18}$

\section{THE ACT, ITS PURPOSE AND APPLICATION}

Four provisions of the Public Service Commission Law govern the issuance of securities by the principal public service companies, namely, sections 55,69, 82 and $101 .^{183}$ The first deals exclusively with security issues by common carriers, railroad corporations and street railroad corporations; the second by gas and electric corporations; the third by steam heating companies; ${ }^{19}$ and the last by telegraph and telephone corporations. Sections 55 and 69 are identical, except for the difference in companies regulated and some other minor dissimilarities.=3 Section 101, however, while closely related, has some substantial differences in its provisions which will be considered later.

The purpose of this legislation was to protect the public, that is, the public in the broadest meaning of the word. It was designed to protect and enforce the rights of the consuming as well as of the investing public; the one from increased rates, the other from improvident investments. And the protection of the public in both of these relations is closely bound up with the efficient operation and proper financing of the companies.

18 "This division was organized in October, 1911, primarily to conduct the accounting examinations of the books of the corporations petitioning the Commission for authority to issue capital stock and other securities. Examination of this character had been made by representatives of the Commission prior to the organization of this division and it was the result of these earlier examinations, as compared with the cr parte showing of the petitioning corporations, which prompted the Commission to institute this division and charge with the conduct before it of all cases involving the issues of securities, mergers, reorganizations and other capitalization matters under its jurisdiction." N. Y. PUB. Ser. Cosim., 2D Dist., Akrivar REP. FOR 1915, xliv-xlv.

"In 1909 there was inaugurated in connection with complicated applications the practice of having examinations made of the bools and records of the petitioners. The necessity of this work continually grew and evidenced itself as the results of such examinations were compared with the ex parte statements of petitioners.... with the 1910 amendment....the establishment of an accounting force for this purpose was rendered imperative. The Division of Capitalization was therefore organized October 5, 1911." N. Y. Pub. Ser. Conimi., 2D Dist., ANnuar Rep. for 1913, 101 $18 a$ N. Y. Cons. Laws (Cahill, 1923) c. 49; N. Y. Ann. Cons. Laws (2d ed. 1917) c. 48 .

19 Section 82 will not be discussed in detail because of the relative unimportance of steam heating companies. The section is similar to sections 55 and 69. Applications for the issuance of securities are made under rule 14, Rules of Practice of the Public Service Commission and rule 14 of the Rules of Practice of the Transit Commission.

20 See People ex rel. Long Acre Electric Light \& Power Co. v. Public Service Commission, 1st Dist., 137 App. Div. 810, 814, 122 N. Y. Supp. 611, 645 (1st Dist. 1910), appeal dismissed 199 N. Y. 254, 92 N. E. 629 (1910). 
As was said in the leading case of People ex rel. Delaware and Hudson Company v. Stevens:

"We understand that the paramount purpose of the enactment of the Public Service Commissions Law was the protection and enforcement of the rights of the public. Public service corporations have been granted valuable franchises to enable them to serve the public, and they are deemed to have undertaken to render to the public the service for which they were incorporated upon receiving a proper and reasonable compensation therefor. - . For a generation or more the public has been frequently imposed upon by the issuance of stocks and bonds of public service corporations for improper purposes, without actual consideration therefor, by company officers seeking to enrich themselves at the expense of innocent and confiding investors. One of the legislative purposes in the enactment of this statute was to correct this evil by enabling the Commission to prevent the issue of such stock and bonds, if upon an investigation of the facts it is found that they were not for the purposes of the corporation enumerated by the statute and reasonably required therefor." ${ }^{21}$

21197 N. Y. 1, 9, 90 N. E. 60, 62 (1909), aff'g 134 App. Div. 90, 118 N. Y. Supp. 969 (3d Dept. 1909).

"The restrictions upon capitalization are designed not merely for the protection of investors and the encouragement of investment in public utilities, but also for the protection of the public from exorbitant or unduly high rates or charges required to reimburse corporations for the use of capital not actually required to perform the service that they render the public. The need of such restrictions has been made very clear by the recent history of the surface car lines in Manhattan Borough, which have been thrown into bankruptcy through the imposition of a burden of fixed charges that went utterly beyond their ability to pay, and that was entirely unwarranted by the actual investment of capital." 1 N. Y. PUB. SER. Comm., 1st Dist., ANNUAL ReP. For 1909, 107.

"The method of determining the amount of the investment or the value of the property upon which a public utility is entitled to a reasonable return has not been finally determined, but there can be no doubt that the nominal capitalization, as represented in stocks and bonds, has in most cases made its influence felt. The necessity of protecting the vested rights of security holders has led to the inclusion in appraisals by companies of every conceivable claim of value, tangible or intangible, not even excluding the value of the very privilege conferred by the community in the way of the franchise. These facts are admitted even by those persons who deny the necessity of public control over the issue of securities; even though they would permit a public service corporation to issue securities without control, they nevertheless insist upon full publicity as to the funds raised by the sale of securities and the use made of such funds in the acquisition of property. There is, therefore, a virtual unanimity of opinion as to the necessity of public control over the property accounts of corporations exercising special franchises." 1 N. Y. PUb. SER. Conim., 1ST Dist., ANNUAL ReP. Fon 1911, $153,154$.

To the same effect:

People ex rel. Binghamton L., H. \& P. Co. v. Stevens, 203 N. Y. 7, 96 N. E. 114 (1911), rev'g 143 App. Div. 789, 128 N. Y. Supp. 440 (3d Dept. 1911) ; People ex rel. New York Edison Co. v. Willcox, 207 N. Y. 86, 93, 100 
The effect of these sections is to require the approval by the commission prior to the issuance of funded or permanent capitalization by the public service companies mentioned. They specify the general purposes for which securities may be issued, namely:

1. Acquisition of property.

2. Construction, completion, extension or improvement of facilities.

3. Improvements or maintenance of service.

4. Discharge or lawful refunding of obligations.

5. Reimbursement of moneys actually expended from income or from moneys in the treasury.

These purposes are exhaustive; it is beyond the power of the Commission to permit issues for any other purpose than those mentioned.22

The sections, in general, require public service companies to apply to the Commission for authority to issue securities. After a hearing, the Commission will approve or disapprove the issue. If it approves, it must make an order specifying the purpose of the issue, the reasonable necessity thereof, and, in case of stocks, that the proceeds will not be used to defray operating expenses. The company can thereafter issue its securities only for the purposes specified and it can apply the proceeds from the securities only as required by the Commission.

The Commission has jurisdiction over the issuance of stocks, bonds, notes or "other evidence of indebtedness." This last phrase refers to obligations of like character to stocks, bonds and notes. ${ }^{23}$ It applies to equipment trust certificates, ${ }^{24}$ guar-

N. E. 705, 706 (1912), rev'g 151 App. Div. 832, 136 N. Y. Supp. 1081 (1st Dept. 1912) ; People v. New York Central \& H. R. R. R., 138 App. Div. 601, 605, 123 N. Y. Supp. 125, 128 (3d Dept. 1910), aff'd 199 N. Y. 539, 92 Nr. E. 1096 (1910) ; In re Mid-Crosstown Ry. (Nos. 1728, 1714) 5 N. Y. PUB. SER CoMmr., 1ST DIST., Rep. of Decisions 22 (1914); In re Northern Light and P. Co., Inc. (No. 757) P. U. R. 1924 B 813 (N. Y. Pub. Ser. Comm. 1923).

22 In re Central Hudson Gas \& Elec. Co., 3 N. Y. Pub. SER Comm., 20 DisT., REP. OF DeCISIONS 380, 385 (1912).

"The enumeration of purposes for which stock, bonds and other evidences of indebtedness may be issued is exclusive and not inclusive, and such securities may not be issued for purposes not enumerated in the statutes either with or without the authorization of the Commission." 1 N. Y. PUB. SER. Comim., 2D DisT., ANNU.AL Rep. for 1908, 10.

${ }^{23}$ People v. New York Central \& H. R. R. R., supra note 21.

24 Venner v. New York Central \& H. R. R. R., 160 App. Div. 127, 142, 145 N. Y. Supp. 725, 735 (3d Dept. 1914), affd 217 N. Y. 615, 111 N. E. 487 (1916); People v. New York Central \& H. R. I. R., supra note 23. For examples see In re Staten Island Midland Co. (No. 1887) $5 \mathrm{~N}$. Y. Pue. SER. Consm., 1ST Dist., ReP. OF Decisroxs 345 (1914); In re New Yorls \& Queens County Ry. Co. (No. 2663) 2 N. Y. Tr.tssir Cosiss, REP. Of Decisions 214 (1922). 
antees and pledges. ${ }^{25}$ It does not, however, apply to such obligation as leases. ${ }^{26}$

The jurisdiction of the Commission extends only to vested or permanent capitalization; ${ }^{27}$ the indebtedness must be payable at a period of more than twelve months after the date thereof. Short time obligations such as notes payable within twelve months may be issued by the companies without the approval of the Commission. They cannot, however, be discharged or refunded by an issue of long time securities without prior authorization of the Commission. ${ }^{28}$

The exercise by the Commission of its regulatory powers over the issuance of securities by public service companies is clearly constitutional. The powers delegated to the Commission are generally recognized as administrative in character ; ${ }^{20}$ the companies for the most part obtain their charters from the State

For text material on the subject of equipment obligations, see DewiNa, Financtal Policy of Corporations (1926) 177 et seq.; DunCaN, Equipment Obligations (1924); Davis \& Brown, Car Trusts in THE UNITED STATES (1894).

25 N. Y. Pub. Ser. Comm., 2d Dist., Annuar Rep. For 1913, 104.

Orders made by the Commission usually contain a prohibition against pledging and hypothecating the securities authorized for loans without the specific approval of the Commission. Such pledging should not be on too disproportionate a basis, as otherwise, in the event of a sale under such hypothecation, the securities of the corporation might be issued without the corporation having received an adequate return.

The execution of a trust deed or mortgage was held an evidence of indebtedness within the Wisconsin Act. In re Wisconsin Utilities Co. (S. B. -1812) 27 Wis. R. R. Comm. ReP. of Decisions 76 (1923).

For a case holding a guaranty an "evidence of indebtedness" see Pollitz v. Public Utilities Comm., 96 Ohio St. 49, 117 N. E. 149 (1917).

${ }^{26}$ People v. New York Central \& H. R. R. R., supra note 21.

Leases of franchises come within $\S \S 54,68$ and 100 of the Act, and must be approved by the Commission.

But see In re Valley Transit Co., P. U. R. 1925E 586 (Cal. R. R. Comm. 1925), wherein it was held that a lease and conditional contract of sale of motor carriers intended to effect consolidation of routes which contained a provision for payment of principal and interest was an evidence of indebtedness within the California Act.

${ }^{27}$ For definition of "Funded Debt," see Ignatius, Financina of Pubuo Service Corporations (1918) § 79, and Uniform Systems of Account prescribed by the Public Service Commission.

28 The Commission disapproved the plan of mortgaging a street railroad to secure demand certificates and an agreement for the pledging of theso certificates by the holder for long time bonds. It said that such an arrangement would nullify and seriously impair the power of the Commission to supervise capitalization and was an evasion of the act. In re Brooklyn Union Elevated Railway Company (Nos. 643 and 642) 2 N. Y. PuB. Ser. Comm., 1st Dist., Annual Rep. for 1908, 111; 1 N. Y. Pub. Ser. Comm., 1ST Dist., ReP. OF Decisions 277 (1908).

29 For a holding to this effect under the similar provisions of the Gas Commission Law, see In re Watertown Gas Light Co., supra note 0. 
of New York, and besides can be regulated under the general power of the state over public service companies. ${ }^{39}$

\section{COMPANIES REGULATED}

The powrer of the Commission over security issues is limited to public service corporations. ${ }^{31}$ In addition, certain of these companies are exempted from its general regulatory jurisdiction; over them it exercises no control in the issuance of corporate securities. Telephone corporations operating not for profit or with property of less value than $\$ 10,000$ are within the exemption; ${ }^{32}$ similarly, gas companies manufacturing and distributing gas over private property for the use of only themselves or their tenants; and also electric companies, owning, operating, or managing a plant and generating or distributing over private property solely for street railway purposes for their own use or the use of their tenants. . $^{33}$

Under sections 55 and 69 , the Commission is given jurisdic-

${ }^{30}$ Section 12 of the Gas Commission Law, which gave the Gas Commission jurisdiction over issuance of securities, was held valid in In re Watertown Gaslight Company, supra note 9.

"The powers imposed upon the Commission by the legislature to regulate public utilities (securities) fall within the exercise of the police powerthe 'least limitable' of the exercise of government." Alabama Public Service Commission v. Mobile Gas Co., $218 \mathrm{Ala}, 50,53,104$ So. 538, 540 (1925).

To the same effect see Public Service Comm. v. Union Pacific R. R., 271 Mio. 258, 262, 197 S. W. 39, 40 (1917) ; Brown v. Boston \& Mie. R. R., 238 MTass. 502, 510, 124* N. E. 322,326 (1919); Laird v. B. \& 0. R. R., 121 IId. 179, 88 Atl. 347 (1913); Public Service Comm. v. Northern Central Ry., 146 IId. 580, 127 Atl. 112 (1924); State v. Great Northern Ry., 100 Minn. 445, 111 N. W. 289 (1907) ; Pittsburgh \& W. Va. Ry. v. I. C. C., 293 Fed. 1001 (C. of A., D. of C. 1923); Davis v. Watertown National Bank, 178 S. W. 593 (Tex. Civ. App. 1915); Wis. So. Ry. v. R. R. Comm., 185 Wis. 313, 201 N. W. 244 (1924); Minn., St. Paul \& S. Ste. MI. Ry. v. R. R. Comm., 183 Wis. 47, 197 N. W. 352 (1924); State ex rel. Miinn., St. Paul \& S. Ste. MI. Ry. v. R. R. Comm., 137 Wis. 80, 117 N. W. 846 (1908).

For a collection of cases on this subject see 41 A. L. R. 891 ct scq.

See also Augusta Trust Co. v. Federal Trust Co., 158 Fed. 157 (C. C. A. 1st, 1907).

For a case holding it unconstitutional to prohibit bonds under and provided for by a mortgage issued prior to the creation of the Commission, see State ex rel. Joplin \& Pittsburgh Ry. v. Public Service Comm., 289 Mo. 452,233 S. W. 388, 838 (1921).

31 In In re White's Express Co. (No. 1228) 2 N. Y. PUB. SER. Coas., 1St Dist., Rep. of Decisions 281 (1910), commented on in 1 N. Y. PUB. Ser. Comint, 1ST Dist., ANNUAl Rep. for 1910, 156, a local express company transferring packages between points in New Yorl: and Broolilyn for certain firms and individuals was held a private carrier and not subject to the Commission's jurisdiction over security issues.

32 Public Service Commission Law, N. Y. Cons. Laws (Cahill, 1928)

c. $49, \S 2$, subdiv. 17 .

${ }^{33}$ Ibid subdiv. 11, 13. 
tion over the security issues of common carriers, railroads, street railroads and gas and electric companies, but its jurisdiction is limited to such corporations as are "organized or existing, or hereafter incorporated, under or by virtue of the laws of New York." This limiting phrase has been said to restrict the jurisdiction of the Commission to those companies incorporated under New York law, and to exclude control over security issues by foreign corporations. This interpretation, which has the support of decisions in other states, is undoubtedly correct. ${ }^{34}$

${ }^{34}$ See IgNatius, op. cit. supra note 27 , at 276.

The Commission went so far as to state that it could not constitutionally be given jurisdiction over capitalization of foreign corporations. It said:

"Attention is called to the fact, that by virtue of the provisions of section 55 and 69 just cited it is possible for this Commission to control only the capitalization of corporations created under or by virtue of the laws of the State of New York. Clearly, the capitalization of foreign corporations is beyond control either of the Legislature of this State or of any commission created by it." N. Y. PUB. Ser. Comm., 2D DisT., ANNUAL REP. FOR 1907, 18.

The Missouri Public Service Commission held that it had no jurisdiction to approve issue of stock by a company incorporated in Delaware and authorized to do business in Missouri, under section 75 of the Public Service Commission Law (Mo. Rev. Stat. (1919) §§ 10483, 10484), which provided:

"A gas corporation......... organized or existing or hereafter incorporated under or by virtue of the laws of this state, may issue stocks, bonds, notes or other evidence of indebtedness, etc............Provided not othorwise, that there shall have been secured from the Commission an order authorizing such issue."

"Said $\$ 75$ limits the authority of the Commission in passing upon issues of stock, bonds, notes or other indebtedness to stock, bonds......... of corporations organized or existing under the laws of this state or hereafter incorporated under the laws of this state." In re Suburban Service Co., P. U. R. 1924B 56, 58 (Mo. Pub. Ser. Comm. 1923).

Sections 54, 55 and 57 of the Missouri Public Service Commission Act do not apply to the issuance of bonds by a railroad company incorporated in Utah even though the lien of the mortgage is on its Missouri property along with the rest. In this case, the mortgage was executed prior to the passage of the Act.

"......the entire authority of a foreign corporation to issue shares of stock grows out of and is limited by the terms of the charter granted to it by the state when it was created. It necessarily results that the right to issue such stock is not a 'special privilege' given by the State of Missouri." Public Service Comm. v. Union Pacific R. R., 271 Mo. 258, 265, $197 \mathrm{~S}$. W. 39, 41 (1917). Also reported in P. U. R. $1917 \mathrm{~F} 774$.

For similar interpretation of like provisions, see In re New England Tol. \& Tel. Co., P. U. R. 1923A, 795 (Me. P. U. Comm. 1922); In re Harbor Tug \& Barge Co., P. U. R. 1926B 811, 815 (Cal. R. R. Comm. 1925).

Compare with the interpretation of statutes which apply to companies "authorized to do business" within the state, in which cases foreign corporations are held to be included within the juxisdiction of the Commissions involved. Peninsular Power Co. v. Secretary of State, 169 Mich. 595 (1012); In re Twin State Gas \& Elec. Co., P. U. R. 1925E 799 (Vt. Pub. Ser. Comm. 1925); In re Erie R. R., P. U. R. 1916 F 408 (N. J. Bd. P. U. Comm'rs, 1916). In this last case a statute placing a limit of eighty cents on the 
Under section 101, however, the Commission is given jurisdiction over telegraph and telephone corporations without limittion as to the character of the companies such as is contained in sections 55 and 69 . The general definition of these types of companies includes both foreign and domestic corporations. ${ }^{35}$ It would seem that in the absence of specific limitation in the securities issue section of the act, the Commission has jurisdiction over the same classes of companies as it has in the exercise of its other regulatory functions and, therefore, controls security issues by both domestic and foreign companies. But under this section, in order that the jurisdiction of the Commission may attach, the proceeds of all or part of the particular issue must be intended for expenditure within the state.

sale price of bonds by companies which have "acquired or may hereafter acquire authority, permission, or a franchise from the state" was held not to apply to foreign corporations operating in the state. On the other hand, a statute giving the commissioners jurisdiction over bonds and evidences of indebtedness issued by corporations or their lessees which "now or hereafter may own, operate or manage or control within the state of New Jersey a steam railroad........ under privileges granted or hereafter to be granted by the state" was held to apply to the issuance of bonds by a New York corporation leasing New Jersey railroads upon which property the bonds were a lien.

A foreign stock corporation need not, under section 20 of the General Corporation Law of New York and section 6 of the Stock Corporation Law, obtain the consent of two-thirds of its stockholders for execution of a mortgage. In re Heffron Co., 216 Fed. 642 (N. N. N. Y. 1914).

In Mruck v. Hitcheock, 212 N. Y. 283, 106 N. E. 75 (1914), a provision that "any foreign corporation" could convey property in the same manner as a domestic one, and section 12 of the Religious Corporation Law was held not to apply to conveyance of New York property by foreign corporations.

A foreign corporation is not doing business within a state by merely maintaining an office and issuing shares of stock therein. Bradbury v. Waukegan \& Washington Mining \& Smelting Co., 113 Ill. App. 600 (1901). Likewise, where it merely holds a meeting therein, and authorizes an issue of bonds. Stephenson v. Dodson, 15 Pa. Dist. 771 (1906).

35 "The provisions of this article shall apply to communication by telegraph or telephone between one point and another within the state of New York and to every telegraph corporation and telephone corporation." PUBiIC Service Commission Law, N. Y. Cons Laws (Cahill, 1923) c. 49, \$90; N. Y. Ann. Cons. Laws (2d ed. 1917) c. 48, $\$ 90$.

36 The New Hampshire Commission has held that although it has no jurisdiction over the issuance of mortgage bonds the proceeds of which are to be expended outside of the state, it has jurisdiction over the mortgaging of property within the state which shall be used as security for the mortgage bonds. In re Springfield Elec. Co., P. U. R. 1917F 604 (N. H. Pub. Ser. Comm. 1917). It also held that it had no jurisdiction over the issuance of notes by a New Hampshire corporation to refund indebtednesses arising out of the purchase and improvement of property outside the state. In re Connecticut River Power Company of N. H., P. U. R. 1915C 37 (N. H. Pub. Ser. Comm. 1915). 
It has been suggested that this latter section is unconstitutional in so far as it attempts to regulate issuance of capital stock by foreign corporations operating in New York. The argument is made that the issuance of capital stock is a corporate function over which the incorporating state alone has jurisdiction; that regulation thereof by any other state amounts to an invalid interference with the internal operation of the corporation; that the power of a state to exclude foreign corporations permits only the imposition of conditions relating to operation of the corporation within the state and not to regulation of the internal affairs of the corporation; and that, accordingly, a state may not impose as a condition to entrance that a company submit to a regulation of its capital stock issues. ${ }^{37}$

The California Commission has held that it has no jurisdiction over the issuance of equipment trust certificates issued for the purpose of acquiring equipment to be used in interstate commerce or in states other than California. In re South Pac. Co., P. U. R. 1921A 58 (Cal. R. R. Comm. 1920).

${ }_{37}$ "While the state may be permitted to exercise a great degree of regulation over the activities of a foreign corporation operating within its borders, its authority is limited to the acts of the corporation in relation to the corporate operations, and cannot be extended to the organization of the corporation or to those acts which the corporation becomes entitled to perform by virtue of the power which gave it existence. As already pointed out, the issue of stock is of the essence of the corporation and must come from the authorization of the incorporating state; if the latter has not authorized the issue of stock, no other state can grant the required authority; the authority of the incorporating state is inherent and therefore primary, and no other state can exercise a power which will tend to impeach or question the authority of that state." IGNATIUs, op cit. supro note 27, at 284 .

The New Hampshire Commission has held that although its statute applies to utilities "lawfully engaged in business" in the state and therefore includes foreign corporations, the Commission has no jurisdiction over the issuance of stock dividends represented by property within tho state where the issuance is by a Maine corporation operated in Maine and New Hampshire.

"Although the language of the statute (N. H. Laws 1915, c. 115), conferring power upon the public service commission to control the issuing of stock by a corporation doing business in this state, is sufficiently broad to include within its provisions foreign corporations, it is not to bo presumed that the legislature intended to give the Commission power to regulate the internal affairs of such corporations. The fact that a foreign corporation engaged in business in this state and owning property located here within the jurisdiction of our courts in suits against it upon its contracts or for fraud practiced by it in the conduct of its business, does not also subject it to legislation purporting to regulate the exercise of the inherent corporate powers conferred upon it by the legislative power of tho incorporating state. North State Mining Co. v. Field, 64 Md. 151, 20 Atl. 1039 (1885); Howell v. Ry., 51 Barb. 378 (N. Y. Sup. Ct. 1868). If the amount of its capital stock is limited by the act of incorporation, the legislature of another state where it happens to be engaged in business has no power to increase or diminish the amount of stock thus fixed and 
There would seem, however, to be little force to this argument. It is conceded that the state may exercise jurisdiction over the encumbrancing of property within its borders, the issuance of mortgage bonds with such property as security, or the borrowing of funds by a corporation. ${ }^{s}$ It derives this

established. One of the apparent reasons for this proposition is the impropriety and futility of interfering in the internal afiairs of the corporation." In re Fryeburg Water Co., 79 N. H. 123, 124, 106 Atl. 225, 226 (1919).

${ }^{38}$ In Williams v. Gaylord, 186 U. S. 157, 165, 22 Sup. Cth 798, 801 (1902), a California statute requiring the consent of two-thirds of the stockholders to execution of a deed by a mining corporation, which statute was by the decisions of the state applied to foreign companies conveying land within the state, was held a valid regulation and was not a regulation of the internal affairs of a foreign corporation. "........ When a corporation sells or encumbers its property, increases debts or gives seeurities, it does business, and a statute regulating such transactions does not regulate the internal affairs of the corporation." The court distinguishes another California statute which required the filing of weelly reports of operation. Such a requirement, it said, would constitute a regulation of internal government of foreign corporations. See IIiles v. Toodward, 115 Cal. 308, 46 Pac. 1076 (1896).

The Williams case was cited, with approval, in In re Eefiron Co., 216 Fed. 642, 647 (N. D. N. Y. 1914).

"It is urged, however, that if the State could, prior to the Transportation Act of 1920, 'constitutionally require the railroad company to secure its consent to a stock issue, it could only do so because there was in this no interference with or regulation of interstate commerce.' But we cannot agree with that argument. For while Congress had the power to regulate the issuance of securities prior to the act, the power was dormant, and until it was exercised the State could, so long as it did not hinder or interfere with the operation of the service of the corporation as an interstate carrier, regulate and control the issuance of its securities, and the test of the State's power was whether its exercise in any given case interfered with or hindered interstate commerce. But when Congress did exercise the power and by appropriate legislation placed the right to regulate and control the issuance of such securities in a federal agency, the power of the State to regulate and control the issuance of securities by an interstate carrier ceased." Public Service Comm. v. Northern Central Ry., supra note 30 , at 589,127 Atl. at 115.

For a case applying the rule that the state wherein the land encumbered lies may regulate the disposition or encumbrancing of the land, see Arndt v. Griggs, 134 U. S. 316, 10 Sup. Ct. 557 (1890); U. S. v. Fox, 94 U. S. 315 (1876) ; Coler v. Tacoma Ry. \& Power Co., 65 N. J. Eq. 347, 54 Atl. 413 (1903).

A foreign corporation coming into a state and doing business therein may be subjected to state laws regulating dissolution and preservation of the life of the corporation for a period thereafter. Castle's Adm. v. Acrogen Coal Co., $145 \mathrm{Kg} .591,140$ S. W. 1034 (1911).

Stock transfer laws as applied to foreign corporations are not an interference with their internal affairs. London, Paris \& Am. B'l v. Aronstein, 117 Fed. 601, 609 (C. C. A. 9th, 1902).

"So far as the issue of securities is concerned, the state may by virtue of its police power require such application, reports and statements to be filed as have a tendency to show whether the proposed issues are bona fide 
power either from control over the property involved or because the activity of the corporation in borrowing money is a form of operation of business in the state. There is no reason to believe that the issuance of capital stock is not similarly a business operation within the state. Of course it is true that in the first instance the incorporating state may determine the amount of capital stock which may lawfully be issued by its creature. But the regulatory functions of the foreign commission need not conflict with the primary authority of the incorporating state: there is no reason to believe that any state commission would be or is authorized to allow an issue of stock when such issue is prohibited by the laws of the incorporating state..$^{\mathrm{sga}}$ The issuance of stock by a corporation which has entered the state to carry on business therein would seem to be as much corporate operation and it would seem as clearly within the power of the state to protect itself from such operation, as in the case of the issuance of notes, mortgage bonds, or any other type of securities. $^{39}$

The New York act, by failing to exclude corporations engaged in interstate commerce, probably includes them, and this inclusion would appear to be no violation of the commerce clause of

and for value....." Laird v. Baltimore \& Ohio R. R., supra note 30, at 188,88 Atl. at 351 .

For various types of regulations see: Meader Furniture Co. v. Commercial Nat. Safe Deposit Co., 192 Fed. 616 (C. C. Ohio, 1911) (statute requiring filing of copies of articles); U. S. Express Co. v. Lucas, 36 Ind. 361 (1871) (file statement of capital employed in business); Cincinnati Mutual Health Assur. Co. v. Rosenthal, 55 Ill. 85 (1870). (insurance companies required to file statement of assets, capital stock, etc.); Washington County Mutual Ins. Co. v. Dawes, 6 Gray 376 (Mass. 1856) (statement of business by insurance companies); Ins. Co. v. Hastings, 2 Allen 398 (Mass. 1861) (same statute); G. Heileman Brewing Co. v. Peimeisl, 85 Minn. 121, 88 N. W. 441 (1901) (proportion of stock represented by property in state and tax therein, fine and disability to sue for violation); Manhattan Trust Co. v. Davis, 23 Mont. 273, 58 Pac. 718 (1899) (file articles and statements with recorders, fine and invalidation of contracts for failure); State ex rol. Coleman v. Western Union Telegraph Co., 75 Kan. 609, 90 Pac. 299 (1907) (file articles, statement of assets, etc. and pay charter fee, forfeiture of right to do business for violation).

38a For application of this principle, see Pollitz v. Wabash R. R., 167 App. Div. 669, 152 N. Y. Supp. 803 (1st Dept. 1915).

${ }_{39}$ Under section $20 \mathrm{a}$ of the Interstate Commerce Commission Act and Transportation Act the issue must be for "a lawful object within its (tho applicant's) corporate purposes." Applied in In re Pittsburgh \& West Virginia Ry. Co. 70 I. C. C. R. 682 (1921).

The Supreme Court has said:

"And we have no doubt of the power of the state to so prescribe, not only from its power over the manners of conveyance and the disposition of property situated within the state, but from its power over foreign corporations doing business within the state." Williams v. Gaylord, supro note 38 , at 167,22 Sup. Ct. at 802. 
the federal constitution. Of course, since Congress has given the Interstate Commerce Commission jurisdiction over the issuance of securities by interstate common carrier railroads except street, suburban or interurban electric railways operating as part of a general steam railroad system of transportation, the Commission is ousted of any possible jurisdiction over such companies. ${ }^{40}$ But in the absence of congressional action it has quite generally been conceded that regulation of security issues by a corporation operating in interstate commerce is not an undue interference with such commerce, but is within the power of the state to protect its citizens from fraud and the evil consequences which have generally arisen from impolitic financing. ${ }^{11}$

40 Act of Feb. 28,1920 , c. $91, \S 439,41$ Stat. 494 (tit. IV of the Transportation Act of 1920); U. S. Code (1925) tit. 49, $\$ 20 \mathrm{a}$. The act applies to the "issue of any share of capital stock or any bond or other evidence of interest in or indebtedness of the carrier.......or to assume any obligation or liability as lessor, lessee, guarantor, indorser, surety, or otherwise, in respect of the securities of any other person, natural or artificial, even though permitted by the authority creating the carrier corporation." This provision undoubtedly covers the issuance of mortgages.

The regulation of securities by the Interstate Commerce Commission was held valid in Pittsburgh \& W. Va. Ry. v. I. C. C., supra note \$0. To same effect see Public Service Comm. v. Northern Central Ry., supra note 30; Minn., St. Paul \& S. S. M. Ry. v. R. R. Comm., supra note 20.

The power of Congress over the holding of securities of interstate railroads so as to affect a restraint of interstate commerce was upheld in Northern Securities Co. v. U. S., 193 U. S. 197, 334, 24 Sup. Ct. 496, $45 j$ (1904).

And the jurisdiction of the Interstate Commerce Commission over securities of companies falling within its provisions was held exclusive in Pub. Ser. Comm. v. Northern C. R. R., 146 IId. 580, 127 Atl. 112 (1924); In re Arizona Eastern R. R. Co., P. U. R. 1926C 705 (Ariz. Corp. Comm. 1926) (mortgage bonds); Public Service Comm. v. Northern Central Ky., supro (capital stock to pay for improvements to property); Minn., St. Paul \& S. S. II. Ry. v. R. R. Comm., supra (notes and mortgage bonds); In re New York Central R. R., 65 I. C. C. R. 534 (1920). The making of its pover exclusive does not invade the powers reserved to the states. Pittsburgh \& W. Va. Ry. v. I. C. C., supra.

On the whole question see the discussion in Railroad Commission v. Southern Pacific Ry. Co.y 264 U. S. 331, 44 Sup. Ct. 376 (1924).

41 For a case recognizing that in the absence of federal legislation states possess and have exercised the power to regulate the issuance of all sorts of securities by interstate carriers without violating the commeree laws, see Minn., St. P. \& S. Ste. MI. Ry. v. R. R. Com. of Wis., supre note 80, at $64,197 \mathrm{~N}$. W. at 359 :

"It has more than three million dollars worth of real property in the State acquired by authority of a statute which imposes the condition that it shall be subject to all the duties, liabilities and provisions of the law of this state concerning railroad corporations as fully as if incorporated in this State (R. S. 1879, see 790). It was incorporated under the laws of Utah, from which it takes its general powers. While we have no doubt that the Congress of the United States might constitute corporations in the 
The jurisdiction of the Commission over holding companies is limited to examination of accounts, rendering reports, and control of relations between the holding and operating companies. It has no direct control over the issuance of securities by a holding company. Only indirectly, by its control over the acquisition of securities of an operating company, can the Com. mission in any way control the issuance of holding company securities. ${ }^{42}$

exercise of its constitutional powers with reference to commerce between the states, we do not think it has even been contended that it might carry the laws of one state into the jurisdiction of another without giving them its own authority by re-enactment. It is incompetent for Utah under any guise to direct how real property within the jurisdiction of this State shall be conveyed, encumbered, or diverted from the use to which it has been devoted by our laws." Union Pac. R. R. v. Public Ser. Comm., 268 Mo. $641,650,187$ S. W. 827,829 (1916). This case was reversed on the ground that the required fee based upon a percentage of the entire issue was unconstitutional. The question of interstate commerce was not taken up. Union Pacific R. R. v. Public Service Comm., 248 U. S. 67, 39 Sup. Ct. 24 (1918).

In Laird v. B. \& O. R. R., supra note 30 , a domestic interstate carrier was held not subject to the control of the State Commission in so far as the amount of its capital stock, convertibility of its bonds into stock or selling price and disposition of the proceeds are concerned. Where the issue of bonds sought were convertible into stock and were issued to refund and make construction largely outside of the state, the act applied to corporations "organized or existing or hereafter incorporated under or by virtuo of the laws of the state of Maryland." The court in its opinion intimated that regulation of security issues of an interstate carrier by a state would violate the commerce clause. The case, however, is a weak one and may be explained largely on the ground that the bonded indebtedness and capitalization of the company was defined in its early charter which was not subject to alteration.

The statement in the above case is weakened by a subsequent pronouncement of the same court. See quotation from Public Service Comm. v. Northern Central Ry., supra note 38 .

The Blue Sky Law regulating the sale of securities in New York by "dealers" does not apply to securities issued or guaranteed by public service corporations, including railroads, which are subject to regulation or supervision as to rates or issuance of securities by a Commission, board or officer of the federal government or any state, nor to equipment trust certificates, notes, or bonds where the ownership or title to the equipment is lawfully pledged or retained. N. Y. Cons. Laws (Cahill, 1923) c. 21, art. 23a, as amended by N. Y. Cons. Laws, Ann. Supp. (Cahill, 1927) c. 21, art. 23a, § 359f. (N. Y. Laws 1925, c. 239).

42 The Commission "has no control over the operations of holding companies except to consent or refuse to permit them to acquire the properties of operating utilities which are within the jurisdiction of the commission." In re Erie Power Corp. (No. 2596): 1 N. Y. PUB. Ser. Comm., ANNual REP. FOR 1925, 276, 279.

In Re Northern Light \& Power Co., supra note 21, an electric company owned by three individuals sought to obtain additional capital, where its property was already covered by a mortgage, by the creation of a holding company, the issuance of securities by the company, and exchange there- 
The Transit Commission has jurisdiction over the issuance of securities by railroads, street railroads, and stage or omnibus lines or routes lying exclusively within a city of over one million inhabitants, that is, within the city of New York. It also has a limited jurisdiction over street railroads and stage or omnibus lines or routes which lie partly within and partly outside New York City. ${ }^{43}$ The Public Service Commission, on the other hand, has jurisdiction over these same companies insofar as concerns the construction, maintenance, stationery equipment, terminal facilities, stations and local transportation facilities outside the territorial limits of the city. ${ }^{\text {is }}$ The Public Service Commission has exclusive jurisdiction in the issuance of securities by railroad corporations otherwise subject to the jurisdiction of both commissions. ${ }^{45}$ Accordingly, it has been held that where a company which was operated as both an electrical and steam railroad company had outstanding underlying bonds which were a lien on both the electrical and steam railroad property and franchise and sought to fund its floating indebtedness and retire

of for the capital stock of an electric company, the exchange to be made on the basis of four shares of the holding company's stoek for one share of the electric company's stock. The intention was later to merge the tro companies and issue further securities for capital improvements. The price placed on the property of the electric company was $\$ \$ 10,000$. The Commission held that it had jurisdiction to require a reduction of price and it did reduce it to $\$ 301,300$. It said that a holding company should not be permitted to purchase the stock of a public service company by issuing four shares of its stock for one of the Public Service Company unless the stock: be worth four times the par value of the stock of the holding company.

The New Jersey Commission, under the provisions of its act (N. J. Laws 1911 , c. $195, \S 19)$ requiring commission consent to the transier by the utilities of more than the majority of the stock to any corporation, held that a utility will not be allowed to transfer all of its stock to a foreign holding company in order to permit the latter to issue sccurities with the stock as a pledge, where the former has sold its property to a holding company at less than its book value without a reduction in capitalization or permission to set up a "property abandonment" account and where it does not appear that the transfer will not so intermingle the management and liabilities of the companies as to make separate operation and supervision impossible. In re New Jersey \& Pa. Traction Co., P. U. R. 1917 A 70 (N. J. Bd. of P. U. Comm'rs, 1916).

The Supreme Court of Ohio held that although the jurisdiction of the Commission extends only to companies furnishing service to consumers, and not to distributing companies, nevertheless, where the stock of several companies is held by a holding company, the corporate fiction will be disregarded and a company furnishing power to a distributing company will be subjected to regulation of rates. Ohio Mining Co. et al v. Public Utilities Commission, 106 O. S. 138 (1922).

43 Public Service Comrmission Law, N. Y. Cons. Laws (Cahill, 1928) c. $49, \S 5 ; \mathrm{N}$. Y. Ann. Cons. Laws (2d ed. 1917) c. $48, \S 5$.

44 Ibid. $§ \S 5,5 \mathrm{a}$.

45 Ibid. $\$ 55$. 
the underlying bonds, it must apply to the Public Service Commission and not the Transit Commission. ${ }^{46}$

\section{PURCHASE OF PROPERTY}

Tangible property may be acquired by a public service com. pany either by new construction of plant and facilities, or by purchase of property already constructed or ready for use in service. $^{47}$ In the first case, the Commission, in judging the amount of securities issuable to cover such purchase, is governed almost entirely by the cost of the construction. The "value" or the property plays no part in its consideration except in extreme cases of abuse of discretion by the company. ${ }^{48}$

In the case of purchase of property completely constructed, the purchase price corresponds in a limited sense to the cost of construction, but it has not the probative force of the latter figure. The primary consideration of the Commission in this class of cases is the value of the property acquired; ${ }^{40}$ the purchase price arrived at by bargaining between purchaser and seller is of great weight in determining such value. It does not establish a figure binding on the Commission, but when determined openly between independent parties is entitled to great probative force in determining the amount of securities which should be allowed for the purchase. ${ }^{50}$ As was said in People ex rel. Westchester Street Ry. v. Public Service Comm.,

${ }_{46}$ In re Richmond Light \& R. R. Co. (No. 2664) 3 N. Y. Transit Comm., REP. OF DECISIONS 81, 99 (1923).

47 "Tangible Capital" comprises structures and equipment having an expectation of life service of more than one year. For definitions see IgNATIUS, op. cit. supra note 27, at 358, and Uniform Systems of Accounts prescribed by the Commission.

Facilities constructed under a limited contract which revert to a third party at the expiration of the contract must be amortized prior to the dato of such reversion. In re Third Avenue Bridge Co. (No. 1435 et al.) 6 N. Y. PUB. Ser. Comim., 1ST Dist., Rep. of Decisions 189 (1915).

Similarly stock issued for the acquisition of an electric power contract must be amortized within the life of the contract. In re Canadian-American Power Corp. (No. 3901 et al.) 4 N. Y. PUB. SER. CoMm., 2D DIST., REP. of DECISIONS 40 (1914).

48 See infra note 70.

49 To the effect that the Commission will refuse its approval to security issues to purchase property where the amount thereof exceeds the fair value of the property acquired, see In re Mid-Crosstown Ry. Co. (Nos. 1728, 1714) 4 N. Y. Pus. SeR. Comm., 1St Dist., Rep. of Decisions 22 (1914).

But a valuation is not necessary where by estimate and comparison the amount of securities quite evidently does not exceed the value of the property. In re New York State G. \& E. Co., P. U. R. $1921 \mathrm{~A} 669$ (N. Y. Pub. Ser. Comm., 2d Dist., 1920).

50 In re New York State G. \& E. Co., supra note 49.

In In re Smith \& Solsville Elec. L. \& P. Co., Inc., (Nos. 6926, 6930) 8 
"The purchase price of property in the open market is generally entitled to great weight in determining the value of such property, but such purchase price is not conclusive evidence of value, and a determination of such amount does not prevent the consideration of other evidence bearing upon the value of the property purchased." 52

N. Y. Pub. Ser. Comm., 2D Dist., Rep. of Decisions 436 (1919), \$20,000 was paid for the conveyance of a small electric plant. The original investment in the plant a short time previous, less depreciation, was $\$ \$ 0,000$. The Commission allowed the issuance of $\$ 30,000$ of securities.

The Commission has allowed a newly organized company to issue securities for working capital determined by the extent of its operation. In re Rochester, Corning, Elmira Traction Co., 1 N. Y. PUR. Ser. Cosus., 20 Dist., ANnuat Rep. for 1908, 13; 1 N. Y. Pub. Ser. Coarar, 2d Dist., Rep. of Decisions 166 (1908); In re New York Dock Ry. (No. 1587) $4 \mathrm{~N}$. Y. Pub. Ser. Comm., 1ST Dist., ReP, of Decisions 94 (1913).

"In these three matters of discount on bonds, working capital, and al lowance for promotion services, the practice is understood to be difierent from that prevailing in Massachusetts. Since 1894, commissions in that State have had control of the amount of securities that public service corporations can issue for any and all purposes. The statutes under which they act are in many respects similar to the Public Service Commissions Law, in this particular: railroads and street railroads must apply to the railroad commission, gas and electric light corporations to the gas and electric light commission and telephone and telegraph, aqueduct and water companies to the commissioner of corporations. Both the railroad and gas and electric light commissions refuse to permit securities to be issued for discount on bonds. It is understood that the railroad commission apparently disapproves of an issue of stock or bonds to provide working capital, but that the gas and electric light commission permits this item to be included in a company's original capitalization.

"The Commission has not found occasion to doubt the correctness of its conclusions upon these points. It has endeavored and will continue to endeavor to make its rulings such as to encourage the investment of capital and the promotion of enterprise. The interests of the public imperatively demand these results and the Commission believes that they are not in the slightest degree inconsistent with the protection of the public against those practices which have justly earned the condemnation of the public and led to the regulation of corporate capitalization by law." $1 \mathrm{~N}$. $\mathrm{Y}$. Pub. Ser. Comm., 2D Dist., ANNUAL Rer. for 1908, 19.

The California Railroad Commission has quite generally allowed the issuance of stock for working capital. In re Bay Transport $\mathrm{C}_{0 .}, \mathrm{P} . \mathrm{U}, \mathbf{R}$. 1922B 769 (Cal. R. R. Comm., 1921); In re Heiskill \& Co., P. U. R. 1926E 219 (Cal. R. R. Comm., 1926); In re Consolidated Ilotor Freight Lines, Ine., P. U. R. 1925B 83 (Cal. R. R. Comm., 1924).

The Wisconsin Railroad Commission appears also to allow such capitalization of working capital. In re Wisconsin-Minnesota I. \& P. Co, P. U. R. 1922C 193 (Wis. R. R. Comm., 1922). In this case, a company was denicd the right to issue bonds to discharge short time obligations for moness borrowed to make its working capital adequate where the lending company was indebted to the applicant on an open account to an amount exceeding the amount of the loan.

51210 N. Y. 456, 459, 101 N. E. 952,953 (1914), modifying 159 App. Div. 251, 143 N. Y. Supp. 148 (3d Dept. 1913). 
The case just quoted from has had a very interesting history. It first appeared before the Public Service Commission of the Second District in the form of an application to issue securities to cover the purchase price of the Tarrytown, White Plains, and Mamaronack Railway Company.52 This road was bid in at a public judicial sale on foreclosure of a mortgage at a price of $\$ 882,400.78$ and the bid was assigned from an individual to the applicant company, which was organized to take over and hold the property. The amount of securities asked for was $\$ 912$,023.46 of stock, which included $\$ 29,622.68$ for legal and other expenses incurred in acquiring the property.

The Commission held that in authorizing the issue it must be governed by the value of the property acquired. After an exhaustive inquiry into the proper standard of value in this class of case, it concluded that rather than follow the standard of value in rate fixing, taxation, or similar cases, it would adopt the standard set forth in sections 55a, 69a and 101a of the Public Service Commissions Law, which apply to reorganizations, namely, a consideration of "original cost of construction, duplication cost, present condition, earning power at reasonable rates, and other relevant matters." The elements for determining value which it found present in the case were reproduction cost less depreciation, past earning power with a general knowledge of prospects of future growth of business, and the price which the property realized at open competitive sale. The reproduction cost less depreciation it found was $\$ 445,693.98$. Operation of the road in the past had resulted in a deficit, but the prospects of profitable operation in the future was good.53 The Commission eliminated the value of the franchise, which had been included in the purchase price, and found that the property had a value for security issue purposes of $\$ 400,000$, plus $\$ 34,000$ for expenses connected with the acquisition of the property.

The Supreme Court reversed the determination of the Commission. ${ }^{54}$ It held in substance that the purchase price at the judicial sale determined the amount of securities which the company could issue, as a matter of right.

52 3 N. Y. Pub. Ser. Comm., 2D Dist., Rep. of Decisions 286 (1912).

53 Commissioner Sague at page 343 in his dissenting opinion disapproved of the emphasis placed on earning power. He said: "One of the main elements of earning power must be the rate which a corporation is permitted to charge. Using earning power as a basis for capitalization, and later using the capitalization as a basis for fixing rates would involve reasoning in a circle." He thought that the most important basis for capitalization was "the money which has been skilfully and economically invested in the property." He said that the company was entitled to the issuance of at least $\$ 450,000$, the reproduction cost less depreciation, and probably somo additional sum for cost of development.

54158 App. Div. 251, 143 N. Y. Supp. 148 (3d Dept. 1913). 
The rates of the road had been found by the Commission to be limited by franchise, in certain of its operations, to five cents. This rate limitation had been declared legal by the Appellate Division of the Supreme Court, and the Commission computed the earning power of the road on the basis of charges under it. The court, in passing on this phase of the case, declared that the Commission should have considered earning power of the company, not at the franchise rate, but at "reasonable rates," because the Commission had power to increase the rate if it was unreasonably low..$^{55}$

The court frankly admitted that the bidding had proceeded on an erroneous idea as to the condition of the property; it said that under such conditions the purchase price was not a binding measure of value. But despite the error, it believed, for some unknown reason, that in the present case securities should be issued for the full purchase price.

"The purchase price at public sale is very satisfactory evidence of the value of property, but it is not always conclusive. It is evident in this case that in one sense the bidding proceeded upon a false basis.

"At the first hearing, the evidence of a competent expert, which was not questioned, indicated that the reproductive value of the physical property was $\$ 679,567.84$. Later, and after the lines had been in part rebuilt, it was found that some of the property which had been given a substantial value was practically worthless and that the property as a whole was not in the condition in which it had seemed to be at the time of the first valuation, and that the actual reproductive value of the property was $\$ 445,693.98$. In other words, the property was found to be $\$ 233,873.86$ less valuable than it appeared at the time of the bidding. In no other respect can the judgment of the New Haven Company or the Westchester Company in making the purchase be questioned. But we hold that under the circumstances the purchaser was entitled to stock for the cost of the purchase." 56

The judgment of the Appellate Division reversing the order and findings of the Commission was in turn amended by the Court of Appeals which found that it was "unable to hold as is held in substance by the Appellate Division that the Westchester Street Railroad Company is entitled, as a matter of law, to the approval . . . of an issue of its stock to an amount at least equal to the bid.

The Appellate Division had disapproved the finding of the value of the property as against the weight of evidence, at least in so far as the finding applied to the issuance of securities.

${ }_{65}$ Ibid. 256, 143 N. Y. Supp. at 152.

56 Ibid. 257, 143 N. Y. Supp. at 153.

57210 N. Y. 456, 459, 104 N. E. 952, 953 (1914). 
Accordingly, the case was remitted to the Commission and both parties given the right to offer further evidence as to value. It does not appear that the case was further litigated.

It has thus been definitely decided that the price at which property is purchased is evidentiary of, but does not determine the amount of securities which may be issued in consummation of the deal. Such is the rule where the price has been determined at a public judicial sale, so clearly it would be such where the price has been arrived at by private bargain. Where the bargain has been made between persons negotiating at arms length, it deserves great weight in determining value. Where, however, the transaction has been made between closely affiliated companies with a common interest, the price has no economic sanction and is therefore entitled to little or no legal weight."s

The Court of Appeals opinion in the Westchester case also inferentially approved the standard of value adopted by the Commission in security issue cases. The Supreme Court corrected the Commission in its use of income figures and inferentially approved the use of earning power as a consideration; but otherwise, nothing was said by either court as to the standard of value. The ruling of the Commission must therefore be still effective that neither exchange value, ${ }^{59}$ nor value as determined by the rule of Smyth $v$. Ames, ${ }^{60}$ nor reproduction cost less de-

68 "The property to be acquired . . . is to be paid for in cash and as the vendor is to hold the common stock of the vendee, and as the two corporations are very closely connected, it is necessary to determine the fair value of the property to be transferred. As the property has not been sold at open competitive sale, it is necessary to resort to estimates and opinions of appraisers. . . ." In re New York Dock Ry. Co., supra note 50 , at 100 .

59 "An inquiry into the value of a railroad property as a whole is an investigation of the question how much will any person or collection of persons desire to possess the property, and how much of money or other things will they be willing to part with for the sake of such possession. The difficulty attending the investigation is: (1) the property has never been, we will assume, bought or sold, so that there is no direct test or evidence of its ratio of exchange for money or other things; (2) it is not one of a class of things which are bought or sold with such frequency or under such circumstances as to afford a fair test of what it would be likely to bring upon exchange or sale." In re Westchester St. Ry. Co., supra note 52 , at 321 .

Bo "If we are to call the language under consideration a rule, the test of its value must be found in its working in a concrete case. Taking the case in hand as a fair example, we find that we have no evidence as to the cost of the property, and it, is a fair assumption from the facts known to us that to ascertain such cost with reasonable precision is impossible. The commercial valuation is an impossibility for the reason that the bonds and stock of the corporations which have owned the property never had any market value. The capitalization of net earnings can not be considered, for in effect there have been no such net earnings. Reproductive cost can 
preciation, are the standards applicable to a security issue case; ${ }^{61}$ but rather that the value should be arrived at by the legislative standard declared for cases of reorganizations, indefinite though it be, namely, a consideration of "original cost of construction, duplication cost, present condition, earning power at reasonable rates and other relevant matters and any additional sum or sums as shall be actually paid in cash," with special emphasis upon the factor of earning power. In the final analysis, earning power is the economic basis upon which the purchase price is fixed and upon which securities should to a large extent be allowed. ${ }^{62}$

The Commission was justified in the Westchester case in taking the rates fixed by the franchise as the basis on which to compute earning power. It must, except perhaps in a rare case of flagrant disparity between the rate fixed by franchise and that which would fairly be a reasonable rate, or in case of change of condition, adopt the past financial record of a company as a

be approximated. If the value of property were always equal to reproductive cost, truly a happy state of affairs would exist. There could be no such thing as loss in venture, except from the depreciation or wear of the property itself. A railroad could be built from nowhere to nowhere without business of any kind and yet its value would continue to be what it would cost to reproduce it. Clearly, the case of Smythe v. Ames is not able to aid the commission materially in the discharge of its duty in this case." In re Westchester St. Ry. Co., supra note 52, at 312.

GI "In capitalizing an existing railroad the commission must, so far as lies within its power, say what is the fair value of the railroad itself. If it takes reproductive cost only to be that value, it goes contrary to all experience and all the sound canons of judgment. A lighting plant constructed in the middle of a desert would have no value as such, for the reason that there would be no one to pay the rate or require the service." In re Westchester St. Ry. Co., supra note 52, at 329.

62" . . . the reproduction cost is not the one element which makes property attractive to an intended purchaser. The attraction lies in the returns that will be afforded." In re Westchester Street Ry. Co., oupra note 52, at 330. See also Dewring, op. cit. supra note 27, at 265 ct scq.

The Federal Industrial Commission in its final report on Transportation stated that a fair basis of capitalization could be found only by taling into consideration both cost of construction and earning capacity. It said on pages 409, 410:

"The chief objection to capitalization on the basis of earning capacity is that it obscures the relation between rates, wages, and profits. It is impossible to discover, without a careful appraisal of the property, whether an overcapitalized road is earning more than a fair return upon the inrestment. The principle is generally accepted at the present time that capital is not entitled to more than a certain fair rate of profits. The issuance of additional securities on the basis of increasing earning power makes it possible for a company covertly to secure exorbitant returns on the actual investment. This objection seems conclusive against the policy of full capitalization up to the limit of earning power." RupLEY, TransPORTATION (Reprint of Chapters on Transportation in final report of Federal Industrial Commission). 
basis of its earning power; otherwise, it would indeed be going through an endless process of fixing values on which to establish rates, using the rates to fix a value on which in turn to establish capitalization, and then, if the generally accepted rules of valuation be applied, in a circular fashion using capitalization as at least of some probative force in fixing the rate base.

\section{FRANCHISES}

The sections of the act under consideration provide that neither primary nor secondary franchises or rights can be capita. lized in excess of the amount actually paid the public therefor. They read:

"Provided, however that the Commission shall have no power to authorize the capitalization of any franchise to be a corporation or to authorize the capitalization of any franchise or the right to own, operate or enjoy any franchise whatsoever in excess of the amount (exclusive of any tax or annual charge) actually paid to the state or any political subdivision thereof as the consideration for the grant of such franchise or right." o3

Under this provision, annual payments to the public for franchise privileges cannot be capitalized, but lump sums paid at the time of the granting of a franchise may form the basis of a security issue. ${ }^{.4}$ Since, however, the franchise, being limited in time, is in the nature of a wasting asset, the sum so capitalized must be amortized during its remaining life. ${ }^{\mathrm{gs}}$

Similarly, expenditures such as those for the purchase of corporate bonds of a city as a condition to the granting of a franchise may be capitalized. When the bonds are to be returned to the company on the expiration of the franchise and in the meantime interest is to be turned over to the company, no amortization is necessary. ${ }^{\text {.6 }}$

B3 Sections 55 and 69 read as above. Section 101 has slightly different phraseology, but is identical in effect.

This provision was applied in In re Dry Dock, East Broadway \& Battery R. R. (No. 1715) 7 N. Y. Pub. Ser. Comm., ISt Dist., ReP. of Decisions 59 (1916).

The inclusion in its rate base of the value of the franchise of the Consolidated Gas Company, as required in Wilcox v. Consolidated Gas Co., 212 U. S. 19, 29 Sup. Ct. 192 (1909), rests upon the peculiarity of the statute under which the company was organized. It is an exception to the rule that franchise values other than actual payments to the state or municipality may not be included in the rate base. See Consolidated Gas Co. v. Newton, 267 Fed. 231,240 (S. D. N. Y. 1920).

${ }^{64}$ In re New York Dock Ry., supra note 50.

${ }^{65}$ Ibid. In this case it was also held that expenditures for organization connected with franchise rights and privileges should be amortized during the life of the franchise.

${ }^{6 B}$ Ibid. 
It has been said by Ignatius that although a franchise may not be capitalized at an amount above the actual expense incurred in payments to the public, when it has been transferred or assigned by the grantee to a third party, then the amount paid for the franchise by the third party may be capitalized by him. ${ }^{c}$ There appears, however, to be no basis for such a statement. The prohibition is against the capitalization of a franchise whether by the initial grantee or his transferee. The evil in any case is the same. If the purchaser of a franchise wishes and finds it necessary to pay more for it in connection with the property acquired than has been paid to the state in consideration for it, such purchaser must finance that part of the purchase price by other means than the issuance of securities. ${ }^{63}$

\section{CONSTRUCTION OF PROPERTY}

Sections 55 and 101 of the act declare "the construction, cornpletion, extension or improvement of its facilities" purposes for which securities may be issued. Section 69 has a similar provision except for the specifying of "plant or distributing system" instead of "facilities."

The principal inquiry by the Commission in this type of case is the actual cost of the construction, unless there is evidence

67 "Where a franchise is acquired through purchase or assignmont, the full amount paid for this acquisition can be capitalized. The transfer is now subject to the authorization of the Commission, which will inquire into the consideration to be paid and the manner of payment, so that the damage of overcapitalization is slight." IGNATIUS, op. cit. supra note 27 , at 871 .

${ }_{68}$ In re. Westchester Street Ry. Co., supra note 52, at 334 ct srq.; In re Mianhattan \& Queens Traction Corp. (No. 1650) N. Y. Pub. SEr. Cosa., IST DIST., REP. OF DEcisions 57 (1914) (wherein sale was previously made to a subsidiary at an increased price).

The California Commission held otherwise in the case of transfer of a motor certificate.

"The certificate of public convenience and necessity proposed to be transferred to the corporation was granted by the Commission without the payment of any fee whatsoever. In my opinion no stock should be permitted to be issued by the corporation for the purpose of acquiring such certificate." In re Jones, P. U. R. $1922 \mathrm{D} 586$ (Cal. R. R. Comm. 1922).

To same effect see In re Auto Transit Co., P. U. R. 1925A 218 (Cal. R. R. Comm. 1924).

The New York Dock Company, after operating a railway on the strects of New York without a franchise formed a subsidiary to operate the road. The city required as a condition to issuance of the franchise to the subsidiary that it pay compensation for the illegal operation of the parent company. The Commission refused to allow the issuance of securities by the subsidiary to cover such payment and required the parent company to repay the subsidiary for amounts expended. In re New Yorl: Dock Ry., supra note 50. See also, Brooklyn Union Gas Co. v. Prendergast, 7 F. (2d) 628,663 (1925), aff'd 272 U. S. 579. 
of inflation or unreasonable and unnecessary payments. ${ }^{09}$ The value of the property acquired has no relevancy as it would in case property already completely constructed were sought to be acquired..$^{70}$ The Commission, in the Westchester Street Railway case, said:

"It should first be noted that there is a clear and broad distinction between capitalization authorized for new construction, in which stock and bonds are to be issued for money and the money expended for materials and labor, and capitalization authorized to purchase completed construction. In the one case stock and bonds are to be issued in exchange for a definite amount of money which is the standard of value, and which at any and all times has a definite although it may be varying exchange value. The money thus obtained, it is true, is to be invested in materials and labor, but it would hardly correspond with the fact to say that the assembled product is of the value of the money expended. In fact, it is rarely if ever of that precise value." 71

The construction in many instances is done under contract with independent construction companies, rather than by the public service company itself. Under such circumstances, the Commission is in no position to question the terms of the contract, except, perhaps, in an extreme case of abuse of discretion on the part of the directors of the company. In the ordinary case, it may not refuse to allow the issuance of securities because the construction contract does not adequately protect the company and the public. ${ }^{72}$ And it will accept the contract price as determinative of the cost of the construction..$^{33}$

But where the construction contract has been made between affiliated companies, and has not been arrived at by genuine bargaining at arms length, there is no assurance that the price fixed approximates the value of the property or what should be its cost. Under such circumstances the contract price will have no weight in determining the amount of securities which should be authorized.

In In re Manhattan and Queens Traction Corporation, a construction company acquired the franchise and property of a traction company by purchase from the receivers thereof. ${ }^{74}$ It then organized a subsidiary corporation for the purpose of taking over the property of the company, and entered into an agreement with this subsidiary to transfer the franchise and property of the traction company, construct a double track electric rail-

${ }^{69}$ In re Manhattan \& Queens Traction Corp., supra note 68, at $68 \mathrm{et}$ seq.

70 See supra page 734.

7 Supra note 52, at 328.

72 People ex rel. Long Acre Elec. L. \& P. Co., supra note 20.

73 In re Manhattan \& Queens Traction Corp., supra note 68 , at 66 et seq.

74 Supra note 68. 
road and other facilities, and guarantee for three years the pay ment of any deficit there might be in the interest of the bonds which it was proposed the subsidiary should issue. In consideration of these obligations, the newly formed corporation agreed to and sought to have authorized the issuance of $\$ 1,500,000$ of mortgage bonds and $\$ 1,488,000$ of stock, all of which were to be delivered to the construction company. Aside from the fact that it would have been illegal for the construction company to hold more than ten per cent of the stock of the railway company, and that the mortgage was not properly assented to by the stockholders, the Commission found that the amount of securities to be issued under the contract had no "reasonable relation to the cost or value of the property to be acquired and that it should have no weight in determining what amount of stocks and bonds may be certified . . a as necessary for the construction of the road." 75

In this case, the Commission authorized the issuance of $\$ 765$,000 of stock, and its sale on the market and payment of that company in cash, rather than transmittal of the securities directly to the construction company. In addition, it approved the issuance of $\$ 807,000$ face value of bonds to be sold at eighty-five, to net $\$ 685,950$, subject to the necessary stockholders' consents and the filing of the proposed mortgage with the Commission.

The Commission will not allow a company to issue securities to finance construction on land in which it has no direct legal interest. Accordingly, where the New York Dock Railway sought to issue stock and bonds to cover the construction of ties, rails and the like which would be located on the land of the New York Dock Company, the sole owner of its capital stock, the Commission refused to allow the issue until a lease should be entered into between the companies and the terms approved by it..$^{i 6}$ It stated that if the lease be a short term one and the new construction revert at its termination to the lessor, or if the property have a mere scrap value at the termination of the lease, the company should "provide a fund, sufiecient, with accumulations, to amortize the cost of such property during the life of the lease or the difference between the cost and the amount which the Dock Railway can realize at its termination."

There are various items which enter into the cost of construction, aside from the cost of the physical materials as such. There are, among other items, the promoter's charge for services and profits $^{77}$ contractor's profit, ${ }^{88}$ cost of engineering, ${ }^{73}$ taxes, $^{87}$ in-

5o Supra note 68, at 74.

${ }^{7}$ In re New York Dock Ry., supra note 50, at 104.

iI In re Rochester, Corning, Elmira Traction Co., supra note 50; In re Eastern Parkway, Brownsville \& East New York Transit Relief Assoc. (No. 2777) 5 N. Y. Transit' Comir., Rep. of Decisioss 104, 107 (1925). 
terest, ${ }^{81}$ insurance and damages during construction, ${ }^{82}$ and legal services and expense of incorporation. ${ }^{\text {2a }}$ These expenses when actually incurred constitute part of the cost of construction.

The Commission requires strict proof of actual cost. Approximate or hypothetical costs are insufficient to support an issue. As was said by Commissioner Maltbie:

"The basis should be actual and necessary net cost, and the ........... company should be required to produce vouchers from the supply companies, and no commissions, fees or profits should be allowed to any allied company. Estimates may serve as a rough guide to determine the approximate amount of stocks and bonds that may be needed, but no payment from security

The Commission refused to allow the issuance of 500 shares preferred stock of a bus company of the par value of $\$ 50,000$ for promoters' services whero no evidence justified the approval of the item either in respect to rendering services or their value.

Several commissions have refused to allow the issuance of securities for promotors' services or profit. But the view, followed in Now York and generally accepted is that promotors are entitled to reasonable compensation and to a profit for their time, energy and constructive efforts in forming the corporation.

Dewing approves of such an allowance. See Dewing, Financial Polioy OF Corporations (1926) 253 et seq., wherein decisions of state Commissions are reviewed.

In the following typical cases allowances were made for such services: In re Eastern Maine R. R., P. U. R. 1916 D 260 (Me. P. U. Comm. 1916) ( $\$ 100,000$ par of stock for promotion of railroad to cost four to five millions); In re Rumford Falls \& Bethel Street Ry., P. U. R. $1917 \mathrm{~B} 898$ (Me. P. U. Comm. 1916) $(\$ 10,000$ in cash instead of $\$ 50,000$ par of stock, as requested, for services in constructing interurban railway thirty miles long); In re River Bend Gas \& Water Co., P. U. R. 1917C 827 (Cal. R. R. Comm. 1917) (stock to net $\$ 5,000$ for promotion and $\$ 1,000$ for legal services for organization and consolidation of gas and water companies valued at about $\$ 120,000$ ); In re Fresno Interurban Ry. Co., P. U. R. 1915A 787 (Cal. R. R. Comm. 1915) $(\$ 4,163$ declared a maximum for construction of 9 miles electric interurban to cost $\$ 145,000$ ) ; In re Crownover Telephone Co., P. U. R. 1921B 579 (Neb. Ry. Comm. 1921) (\$2,145.30 for telephone company with $\$ 30,000$ assets).

78 In re Manhattan \& Queens Traction Corp., supra note 68.

${ }^{79}$ In re Syracuse \& Suburban R. R. (No. 6512) 1 N. Y. PuB. SER. Comm., 2D Dist., ANNuAx Rep. For 1918, 356, 357. In this case, the Commission allowed engineering costs to be charged to capital account only if performed by other than regular officers or employees of the company, or if not performed by them under express assignment to the construction or improvement work.

${ }^{80}$ In re Third Avenue Bridge Co., supra note 47 (franchise payments prior to operation); In re Twenty-third Street Ry. Co. (No. 1584) 4 N. Y. PUb. Ser. Comm., IST Dist., Rep. of Decisions, 283 (1913).

${ }^{81}$ In re Central Hudson G. \& E. Co., supra note 22, at 390 ; In re Twentythird Street Ry., supra note 80 .

82 In re Twenty-third Street Ry., supra note 80.

82a In re Eastern Parkway, Brownsville \& East New York Transit Relief Assoc., supra note 77. 
issues or charges to capital account should be made upon the basis of probable or hypothetical cost." ${ }^{83}$

The amount of securities allowed by the Commission for the new construction is necessarily based upon estimates of probable cost. The actual expense incurred may or may not conform to the amount of proceeds derived from the sale of the securities, according to the accuracy of the estimate. The Commission should in all cases require that excess proceeds be used only for purposes provided by its order. Certain types of construction are complicated in character and difficult to estimate. In such cases, the Commission should lean toward the side of allowing an under-capitalization rather than an over-capitalization. It is always possible, if the amount allowed is insufficient, for the company to apply to the Commission for authorization of an additional amount. ${ }^{84}$

(To be continued)

${ }^{83}$ In re Manhattan \& Queens Traction Corp., supra note 68, at 74.

84 "The order authorizing such stock and bond issues (capitalization of newly organized company) will contain appropriate provisions designed to secure the construction of the road in accordance with the plans and specifications upon which the authorization was made and not in excess of the actual requirements.

"If the allowance proves inadequate for the required purposes, an application for further capitalization may be made, upon which application the expenditure of the proceeds of stock and bonds already authorized must be shown in detail." In re Rochester, Corning, Elmira Traction Co., supra note 50, at 14, 1 REP. OF DEcISIONS at 168 .

"The Commission is aware that in most cases it is possible to arrive only at a reasonable approximation of the cost of proposed construction, and that no engineer can forsee with accuracy all of the difficulties and expenses to be encountered in a proposed work. It is, however, of the highest importance that the spirit and purpose of the law shall be carried out in good faith; and it is far better that there should be an under capitalization permitted by this Commission, in which event the corporation can apply for a further issue of securities, than that an over capitalization should be allowed which would permit the possibility of the corporation diverting the proceeds to purposes not warranted by the application, as well as create a charge upon the company, to meet which it will be contended that revenue derived from the public must be supplied.

"It is also apparent that in conducting the investigations requisite to decide properly the questions of fact presented to the Commission, it is necessary to have the services of skilled engineers and experts to advise the Commission as to the cost of proposed constructions. In cases of any importance, the Commission requires the applicant to produce its engineers before it, that they may be examined orally and in detail as to their estimates; but this is not deemed sufficient. In some classes of construction there is no difficulty in arriving at the fair cost thereof, but in other and the really important cases, involving a multitude of details and a variety of unit costs, it is of the highest importance that the Commission should be in possession of complete and detailed information as to such costs. It has employed, therefore, in the division of light, heat and power, an electrical engineer believed to be thoroughly familiar with such matters and upon whose judgment it can lean with safety." N. Y. PUB. SER. Cosss., 20 DIST., ANNUAL REP. FOR 1907, 21. 